\title{
The vuvuzela sounds
}

\section{Jon Patricios}

Traditionally made from and inspired by a kudu (antelope) horn, the vuvuzela was used in Africa to summon distant villagers to attend community gatherings. One of the lasting impressions left on many who witnessed the 2010 FIFA World Cup is of the persistent and somewhat monotonous sound of the modern-day version of this instrument blown relentlessly by South Africans and, somewhat contagiously, by international supporters as well. In a metaphorical sense, South Africans and the sports medicine community, in particular, are again sounding their vuvuzelas imploring the world to take notice. The theme this time is the further development of an ethos of sports medicine excellence on our continent and in South Africa, in particular.

\section{African medical and scientific excellence}

We celebrate the President of FIFA awarding South Africa '9 out of 10' for hosting the World Cup in 2010. This is just one example of successful high-profile sporting events held in South Africa. Interestingly, Johannesburg is one of only two cities in the world to have hosted World Cup finals in soccer, rugby and cricket.

Can success in medicine and science parallel Africa's prowess on the sporting field? On a continent where tuberculosis, HIV/AIDS and malaria rank higher on the medical priority list than, for instance, an RCT to determine the efficacy of PRP in muscle tears, sports physicians, exercise scientists and researchers need to make the most of very limited resources. Thus, international collaboration is an excellent way of 'leveraging' local expertise. This 'South Africanguided' BJSM issue features prominent South African researchers; the paper that includes South Africans Schwellnus and Derman publishing with FIFA is an excellent illustration of such collaborative work (see page 626).

Correspondence to Jon Patricios, South African Sports Medicine Association, P0 Box 1267 , Parklands, 2121, South Africa; jpat@mweb.co.za

\section{African-international partnerships in sports medicine}

South Africa boasts two FIFA Medical Centres of Excellence (http://www.fifa. com) aimed at promoting research in the 'beautiful game', whereas Cape Town hosts one of four IOC Research Centres (http://web.uct.ac.za/depts/essm/). These illustrate the synergy of regional and international partners and highlight that South Africa contributes world-class researchers as well as a wonderful setting for studying a diverse sporting culture and population. Examples of cross-continental research and clinical partnerships featuring South Africans exist in such fields as tendinopathy, ${ }^{1} 2$ genomics, ${ }^{2}$ concussion and football medicine. ${ }^{3}$ Importantly, the concepts of exercise-associated hyponatraemia ${ }^{4}$ and the Central Governor Model arose from South Africa. ${ }^{5}$ Similarly, African sports clinicians serve on major committees such as FIFA, FIMS and ISAKOS, and they feature prominently on academic programmes hosted by both the American College of Sports Medicine and the International Olympic Committee. But the likes of Noakes, Schwellnus, Derman and Collins will not be around forever (even though they practice what they preach!). The African sport and exercise medicine cohort must increase in size - in scientific parlance, a greater ' $\mathrm{N}$ ' will make us more powerful. An important facilitator is the path being paved for full specialty recognition in South Africa, which means there has never been a more opportune time for young clinicians to embark on this most exciting career.

\section{The 14th Biennial South African Sports Medicine Association Congress}

The SASMA Congress is exactly the forum for young African clinicians and researchers to mingle with the sports medicine elite. In Durban, in 2009, our conference theme was 'Back to Basics'. This year, October 18-20 at the Sandton Convention Centre, Johannesburg, we will extend this notion by seeking to go 'From Basics to Brilliant - World Class in Africa'.
SASMA 2011 will be a time to talk Collagen with Cook, Kinetics with Kibler and Surgery with Siekmann. There will be an opportunity to be 'hip' by witnessing live FAI surgery, have breakfast with Burke and meet the man who described the 'Noble's test' for ITB. Please accept this invitation to savour our hospitality and witness first hand 'African Excellence'. See the final programme at http://www.sasma. org.za and follow the BJSM blog (http:// blogs.bmj.com/bjsm/) for updates. I'll be discussing the programme on a brief BJSM podcast (http://podcasts.bmj.com/bjsm).

Hosting the meeting in Johannesburg is not without significance as it is in this region known as the 'Cradle of Humankind' that our ancestors developed the biological features that define our anatomy, physiology and exercise potential. Human sporting ability may be the direct result of the selective survival pressures faced by our hominid ancestors as they evolved over the past 3 million years in Southern Africa.

It is time to again answer the call of the vuvuzela as a new generation in sport and exercise medicine join established mentors and strive to be 'World Class in Africa'. It is possible, just ask Sepp Blatter!

Competing interests JP is the President of the South African Sports Medicine Association. He has an emotional stake in the success of the 2011 Congress but no financial involvement.

Provenance and peer review Commissioned; internally peer reviewed.

Accepted 19 April 2011

Br J Sports Med 2011;45:607.

doi:10.1136/bjsports-2011-090136

\section{REFERENCES}

1. September AV, Cook J, Handley CJ, et al. Variants within the COL5A1 gene are associated with Achilles tendinopathy in two populations. Br J Sports Med 2009;43:357-65.

2. Mokone GG, Gajjar M, September AV, et al. The guanine-thymine dinucleotide repeat polymorphism within the tenascin- $C$ gene is associated with achilles tendon injuries. Am J Sports Med 2005;33:1016-21.

3. Ljungqvist A, Jenoure PJ, Engebretsen L, et al. The International Olympic Committee (IOC) consensus statement on periodic health evaluation of elite athletes, March 2009. Clin J Sport Med 2009;19:347-65.

4. Noakes TD, Goodwin N, Rayner BL, et al. Water intoxication: a possible complication during endurance exercise. Med Sci Sports Exerc 1985;17:370-5.

5. Noakes TD. 1996 J.B. Wolffe Memorial Lecture. Challenging beliefs: ex Africa semper aliquid novi. Med Sci Sports Exerc 1997;29:571-90. 